\title{
USO DA INFORMAÇÃO A PRIORI NO EMPILHAMENTO CRS: UM ESTUDO COMPARATIVO COM O EMPILHAMENTO CMP
}

\author{
Izaias Martins Júnior \\ Orientador: Dr. Marco Antonio Barsottelli Botelho (UFBA) \\ 140 p. - Dissertação (Mestrado) - Defesa 24.08.2007
}

\begin{abstract}
RESUMO. A busca por métodos de imageamento da subsuperfície terrestre cada vez mais precisos tem sido de grande interesse da indústria petrolífera, isto porque, os reservatórios de hidrocarbonetos ocorrem normalmente em porções de bacias sedimentares que apresentam estruturas geológicas complexas. Atendendo esta demanda, surgiu, na última virada de século, uma nova técnica de processamento de dados sísmicos denominada CRS (Common Reflection Surface). A qual efetua o empilhamento dos dados para simular seções de afastamento nulo (zero-offset) e tem como vantagem sobre as técnicas tradicionais uma independência do macro modelo de velocidades. Neste trabalho apresentamos 0 conceito do novo método de empilhamento, bem como as etapas necessárias para que o método seja usado no processamento dos dados sísmicos. Abordamos também alguns conceitos a respeito do método clássico de processamento de dados sísmicos, o convencional CMP (Common Midpoint). Aplicamos o novo método de empilhamento CRS em três diferentes conjuntos de dados sísmicos: $\left(1^{\circ}\right)$ em dados marinhos sintéticos, conhecidos como Marmousi, que são baseados em informações reais de perfilagem marinha na Bacia de Cuanza, em Angola, $\left(2^{\circ}\right)$ em dados marinhos reais levantados sobre a quebra do talude da Bacia do Jequitinhonha da linha sísmica 214-0266, (3०) em dados terrestres reais da Bacia do Tacutu da linha sísmica RL50-90. Mesmo sendo independente de um macromodelo de velocidades, o método de empilhamento CRS admite 0 uso de um campo de velocidades como parâmetro inicial do processamento, desta maneira, avaliamos neste trabalho a eficiência do uso do conhecimento a priori de um campo de velocidades no empilhamento CRS dos três dados sísmicos citados anteriormente. Ao término do processo de empilhamento, os dados foram migrados com o método de deslocamento de fase (Phase Shift) e os resultados dos métodos de empilhamento foram então comparados.
\end{abstract}

ABSTRACT. The search for new accurate methods that imagine the earth subsurface has been of great interest of the petroliferous industry, this reason, the hydrocarbon reservoir normally occurs in portion of sedimentary basins that presents complex geological structures. Taking care of this demand, appeared in the last century, a new technique of seismic data processing namely CRS (Common Reflection Surface). Which product a stacked section, that simulate a zero offset section and has as advantage on the others traditional techniques an macro velocity model independence. In this work we present the concepts of the new stack method, besides, the necessary stapes used in the seismic data processing. We also approach some concepts regarding of the classic method of seismic data processing, the conventional CMP (Common Midpoint). We applied the new CRS stack method in three different seismic data sets: $\left(1^{\text {st }}\right)$ in the synthetics marines data sets, known as Marmousi, that they are based on real information of marine profile in the Cuanza Basin, in Angola, $\left(2^{\text {nd }}\right)$ in real marines data sets, acquired over the slope of the Jequitinhonha Basin of the seismic line 214-0266, $\left(3^{\text {rd }}\right)$ in the terrestrial data sets of the Tacutu Basin of the seismic line RL50-90. Even it is macro velocity model independent, the CRS stack method admit that the velocity field has used as inner parameter on the processing, in this way, we evaluated in this work the efficiency of the use of the priori knowledge of the velocity field in the CRS stack of the three cited seismic data sets. To the ending of the stacking process, the seismic data sets were migrated with the Phase Shift method and of the staking methods were compared. 